\title{
CAEP 2014 Academic Symposium: "How to make research succeed in your emergency department: How to develop and train career researchers in emergency medicine"
}

\author{
Jeffrey J. Perry, MD, MSc ${ }^{*}$; Carolyn E. Snider, MD, MPH ; Jennifer D. Artz, PhD"; \\ lan G. Stiell, MD, MSc ${ }^{* \dagger}$; Sedigheh Shaeri, MD ${ }^{\neq \neq}$; Shelley McLeod, MSc**; Natalie Le Sage, MD, PhD ${ }^{+\dagger}$; \\ Corinne Hohl, MD, MSc ${ }^{\S}$; Lisa A. Calder, MD, MSc ${ }^{*{ }^{+}}$; Christian Vaillancourt, MD, MSc ${ }^{*+}$; \\ Brian Holroyd, MD, MBA ${ }^{\text {Ifा; }}$ Judd E. Hollander, MD***; Laurie J. Morrison, MD, MSc ${ }^{\ddagger \ddagger \S \S}$
}

\section{ABSTRACT}

Objectives: We sought to 1) identify best practices for training and mentoring clinician researchers, 2) characterize facilitators and barriers for Canadian emergency medicine researchers, and 3) develop pragmatic recommendations to improve and standardize emergency medicine postgraduate research training programs to build research capacity.

Methods: We performed a systematic review of MEDLINE and Embase using search terms relevant to emergency medicine research fellowship/graduate training. We conducted an email survey of all Canadian emergency physician researchers. The Society for Academic Emergency Medicine (SAEM) research fellowship program was analysed, and other similar international programs were sought. An expert panel reviewed these data and presented recommendations at the Canadian Association of Emergency Physicians (CAEP) 2014 Academic Symposium. We refined our recommendations based on feedback received.

Results: Of 1,246 potentially relevant citations, we included 10 articles. We identified five key themes: 1) creating training opportunities; 2) ensuring adequate protected time; 3) salary support; 4) infrastructure; and 5) mentorship. Our survey achieved a $72 \%$ (67/93) response rate. From these responses, $42(63 \%)$ consider themselves clinical researchers (i.e., spend a significant proportion of their career conducting research). The single largest constraint to conducting research was funding. Factors felt to be positive contributors to a clinical research career included salary support, research training (including an advanced graduate degree), mentorship, and infrastructure. The SAEM research fellowship was the only emergency medicine research fellowship program identified. This 2-year program requires approval of both the teaching centre and each applying fellow. This program requires training in 15 core competencies, manuscript preparation, and submission of a large grant to a national peer-review funding organization.

Conclusions: We recommend that the CAEP Academic Section create a process to endorse research fellowship/ graduate training programs. These programs should include two phases: Phase I: Research fellowship/graduate training would include an advanced research university degree and 15 core learning areas. Phase II: research consolidation involves a further 1-3 years with an emphasis on mentorship and scholarship production. It is anticipated that clinician scientists completing Phase I and Phase II training at a CAEP Academic Section-endorsed site(s) will be independent researchers with a higher likelihood of securing external peer-reviewed funding and be able to have a meaningful external impact in emergency medicine research.

\section{RÉSUMÉ}

Objectifs: Le groupe visait à: 1) relever les pratiques exemplaires en matière de formation et de mentorat des cliniciens-chercheurs; 2) caractériser les facteurs facilitants de la recherche en médecine d'urgence au Canada ainsi que les

\begin{abstract}
From the *University of Ottawa, Department of Emergency Medicine, Ottawa, ON; †Ottawa Hospital Research Institute, Clinical Epidemiology Program, Ottawa, ON; ¥University of Manitoba, Department of Emergency Medicine, Winnipeg, MB; §University of British Columbia, Department of Emergency Medicine and Vancouver Coastal Health, Vancouver, BC; ๆCanadian Association of Emergency Physicians, Ottawa, ON; **The University of Western Ontario, Department of Medicine, Division of Emergency Medicine, London, ON; ††Department of Family Medicine and Emergency Medicine, Université Laval and CHU de Québec Research Center, Quebec City, QC; ¥¥Rescu, Li Ka Shing Knowledge Institute, St. Michael's Hospital, Toronto, ON; §§Division of Emergency Medicine, Department of Medicine, University of Toronto, Toronto, ON; TाDepartment of Emergency Medicine, University of Alberta, Edmonton, AB; and ***Department of Emergency Medicine, Sidney Kimmel Medical College of Thomas Jefferson University, Philadelphia, PA.
\end{abstract}

Correspondence to: Dr. Jeffrey J. Perry, Ottawa Hospital, Civic Campus, Clinical Epidemiology Unit F647, 1053 Carling Avenue, Ottawa, ON K1Y 4E9; Email: jperry@ohri.ca 
obstacles; 3) élaborer des recommandations pragmatiques pour améliorer et normaliser les programmes de formation de cycles supérieurs en recherche dans le domaine de la médecine d'urgence afin de constituer une capacité de recherche.

Méthode: Le groupe a procédé à une revue systématique dans MEDLINE et Embase, à l'aide de termes de recherche se rapportant à la formation de cycles supérieurs et aux bourses de recherche en médecine d'urgence. Une enquête a été menée, par courriel, parmi tous les cliniciens-chercheurs en médecine d'urgence au Canada. Le programme de bourses de recherche de la Society for Academic Emergency Medicine (SAEM) a fait l'objet d'analyse, et des recherches ont été entreprises sur d'autres programmes internationaux similaires. Un groupe d'experts a examiné les données et présenté des recommandations à l'occasion du symposium sur les affaires universitaires de l'Association canadienne des médecins d'urgence (ACMU), de 2014. Les recommandations ont par la suite été améliorées d'après les observations reçues.

Résultats: Sur 1246 citations potentiellement pertinentes, 10 articles ont été retenus. Se sont dégagés cinq grands thèmes: 1) la création de possibilités de formation; 2) une période de protection suffisamment longue; 3) I'aide salariale; 4) I'infrastructure; et 5) le mentorat. Le taux de réponse à l'enquête s'est élevé à $72 \%$ (67/93) et, parmi les répondants, 42 (63\%) se considéraient comme des cliniciens-chercheurs (c'est-àdire qu'ils passent une grande partie de leur carrière à faire de la recherche). Le seul gros obstacle à la recherche était les efforts pour obtenir du financement; quant aux facteurs perçus comme favorables à une carrière en recherche clinique, il y avait l'aide salariale, la formation en recherche comprenant un diplôme de cycles supérieurs en la matière, le mentorat et l'infrastructure. Les bourses de recherche de la SAEM étaient le seul programme de bourses de recherche en médecine d'urgence qui a pu être relevé. II s'agit d'un programme de deux ans, qui nécessite l'approbation et du centre d'enseignement et de chacun des candidats/candidates. Les exigences du programme comprennent de la formation dans 15 compétences de base, la préparation d'articles et la présentation d'une demande d'une subvention importante à une organisation nationale de financement évalué par les pairs.

Conclusions: Le groupe recommande que la section de I'ACMU responsable des affaires universitaires élabore un processus visant à appuyer les programmes de formation de cycles supérieurs et de bourses de recherche. Ces programmes devraient se diviser en deux phases: la première, axée sur une formation de cycles supérieurs et de bourses de recherche, comprendrait l'obtention d'un diplôme universitaire en recherche avancée et dans 15 champs d'apprentissage de base; la seconde, axée sur la consolidation des acquis en recherche, d'une durée de 1 à 3 ans additionnels, porterait en grande partie sur le mentorat et la production d'articles savants. Les chercheurs-cliniciens qui réaliseraient les deux phases de la formation dans un des centres de recherche reconnus par la section des affaires universitaires de I'ACMU deviendraient des chercheurs indépendants, qui auraient de bonnes chances d'obtenir du financement externe, évalué par les pairs, et de faire de la recherche susceptible d'un large rayonnement externe en médecine d'urgence.

Keywords: emergency medicine, fellowship, graduate training, research

\section{INTRODUCTION}

Emergency medicine is a dynamic field with rapidly evolving practices. New evidence has greatly altered practice over the last 20 years. The specialty of emergency medicine may be an ideal specialty for studying many acute emergencies with a broad mix of patients and conditions to analyse. However, there are relatively few emergency physicians in Canada who dedicate substantial amounts of their career to conducting research. Furthermore, obtaining salary support for clinician scientists is increasingly difficult in Canada. Traditional sources, including the Canadian Institutes of Health Research and the Heart and Stroke Foundation of Canada, offer few salary awards, making these opportunities for funding extremely competitive. Research funding for operating grants is likewise competitive, with recent success rates around $20 \%$. Given that emergency physicians are competing against clinician scientists from all fields of medicine, it is imperative that emergency medicine clinician scientists be optimally prepared to achieve success.

Writing grants, manuscripts, and presenting scientific findings are some of the critical skills required of clinician scientists. However, these traits are not intuitive, and they are not routinely taught to potential scientists. Further, it is not clear what skills and knowledge are essential for Canadian emergency medicine clinician scientists. There are essential stepping stones to success in research that have been defined in other specialties, which include mentorship, graduate training, salary support, and infrastructure. ${ }^{1,2}$ Adding to the complexity of the current research training landscape are variations in training programs, degrees offered, and expertise available for mentorship.

\section{OBJECTIVES}

We sought to 1) identify recommended practices for training and mentoring clinician scientists, 2) characterize 
facilitators and barriers for Canadian emergency medicine scientists, and 3) develop pragmatic recommendations to improve and standardize emergency medicine clinician scientist training programs to promote growth and success in research within emergency medicine in Canada.

\section{METHODS}

\section{Design}

We assembled an expert panel (six members) and advisory committee (four members), which included emergency physician representation from across Canada and the Society for Academic Emergency Medicine (SAEM) in the United States. We systematically reviewed the existing literature on research training and mentoring, conducted a national survey of emergency medicine researchers, and assessed other emergency medicine training programs. Using these data, we developed preliminary recommendations via a consensus process with experts in emergency medicine research. We refined our recommendations based on discussions at the national Academic Symposium held at the Canadian Association of Emergency Physicians (CAEP) 2014 National Conference, in Ottawa. ${ }^{3,4,5}$

\section{Systematic literature review}

We sought to answer the question, "How can emergency medicine programs enhance research training and mentoring to maximize the number of trained clinician scientists in emergency medicine?" We sought to find any articles, including emergency physician research fellows, trainees, junior faculty, or researchers who described research training, graduate training, or mentoring. The primary outcome of the included studies included a program evaluation or description. Secondary outcomes of interest were assessing productivity of clinical researchers. With the assistance of an information scientist, we developed a search strategy using a combination of predefined $\mathrm{MeSH}$ headings and free text words (Appendix 1). We searched MEDLINE and Embase using Ovid from 1946 to January 9, 2014, restricting language to English or French. All potentially relevant citations were independently reviewed by at least two authors (JP, CS or SS), and disagreements were resolved by a third vote. We hand-searched reference lists of the retrieved studies for additional relevant citations. We excluded editorials or letters to the editor. The resulting articles were assessed for relevance, and common themes were abstracted independently by two investigators (CS, SS).

\section{Survey}

Through an iterative process, we developed a 39-item online survey instrument designed to assess four broad categories from clinical researchers: 1) time and financial compensation; 2) satisfaction of each aspect of career; 3) facilitators to research success; and 4) barriers to conducting research. Prior to distribution, we piloted the survey among panel members for ease of use and understanding. The names and email addresses of Canadian emergency medicine clinician researchers were generated from an environmental scan of all 17 Canadian university emergency medicine training programs, including their respective teaching hospitals (median 3, ranging from 1-6 hospitals per university), conducted separately by the Academic Section of CAEP from August to December 2013. The email was sent to the department heads, resident directors, and research directors at each institution. Non-responders were contacted by telephone if they did not reply to repeated emails. Answers appearing to be incorrect or incomplete were questioned at the source. This environmental scan requested the names and contact information for clinician scientists in emergency medicine, and this generated a list of 93 possible clinician researchers. All sites provided responses. The names on this list were further assessed by our panel to identify any known missing researchers. No additional names were added. The final survey instrument was administered online using Fluid Surveys (Fluidware Corporation, Ottawa, ON). A pre-notification email was distributed 2 days before the survey instrument, which included assurances about privacy and restricted release of data in aggregate form. Respondents received up to three email reminders at 2-week intervals. We analysed the resulting data using descriptive statistics reporting means, medians, and proportions, as appropriate.

We sought to review the criteria of the SAEM research training certificate and determine whether these criteria fulfil the requirements identified on the systematic review, address issues in our survey, and are applicable to a Canadian setting. 


\section{Recommendation development}

We derived the recommendations by group consensus in an iterative fashion after review and discussion of the existing literature, our survey data, and review of the SAEM research fellowship training guidelines. Once refined, we presented the draft recommendations for discussion at the Academic Symposium at the CAEP 2014 Annual Conference, which was attended by 80 individuals, including emergency medicine clinical researchers, educators, administrators, attending emergency physicians, and residents. The final recommendations were subsequently revised based on the feedback from the approach previously listed.

\section{RESULTS}

\section{Systematic literature review}

Our search yielded 1,246 citations. After eliminating duplicate citations $(n=379)$ and articles that did not meet eligibility criteria $(n=830), 37$ full-text articles were retrieved for complete review (Figure 1). Twentyseven were subsequently excluded, leaving 10 articles included in the review. A summary of the included articles is listed in Table 1, with the results stratified by focus (emergency medical services, education, and general

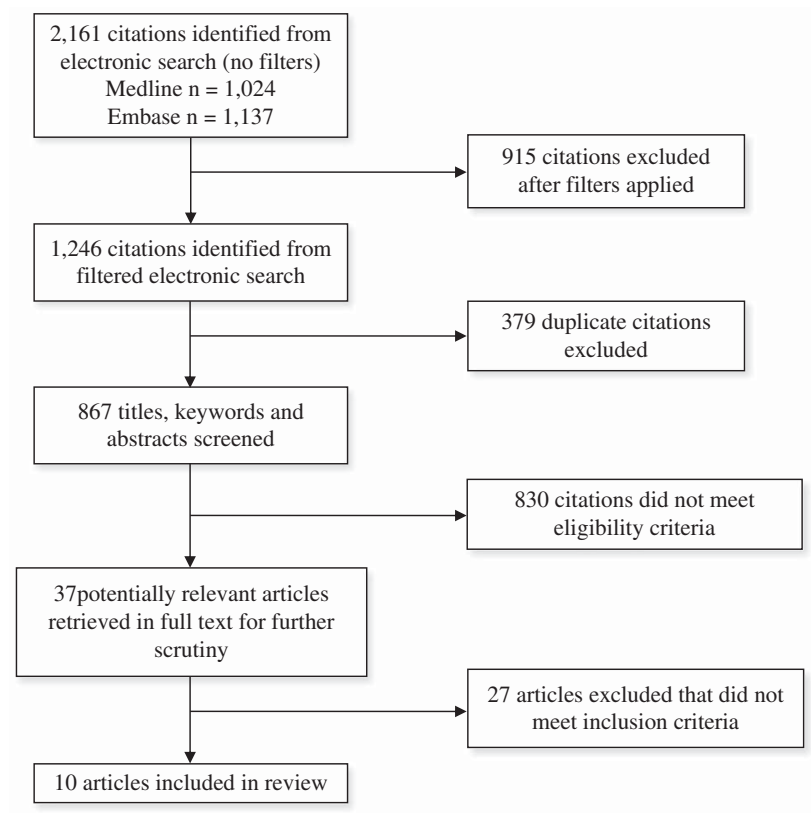

Figure 1. Flow of article selection from systematic literature review of MEDLINE and Embase. emergency medicine). All of the included articles were opinion pieces or summaries from consensus conferences, and data revolved around five themes: 1) creating training opportunities; 2) ensuring adequate protected time; 3) salary support; 4) infrastructure; and 5) mentorship. ${ }^{6-15}$

\section{Survey}

We achieved a $72 \%$ (67/93) response rate for our national survey. Respondents represented 8 of the 10 provinces and the Yukon Territory. Of the respondents, $42(63 \%)$ self-identified themselves as clinical researchers. The others categorized themselves as educators, education researchers, clinicians (with research on the side), emergency medical service directors, or administrators. Table 2 describes the characteristics of the clinical researchers. Over twothirds $(n=29)$ of the clinical researchers were FRCPCEM-trained (i.e., 5-year emergency medicine residency administered by the Royal College of Physicians and Surgeons of Canada) or had FRCPC-Pediatrics EM fellowship training (i.e., 4-year pediatrics residency with 2-3 years of pediatric emergency fellowship). About one-quarter $(n=10)$ were CFPC-EM-trained (i.e., 2 -year family medicine residency followed by 1 -year of emergency medicine residency administered by the College of Family Physicians of Canada). Approximately two-thirds $(n=29)$ stated that they have graduate research training. A master's degree in epidemiology was the most common training (51\%).

The median number of hours worked per week was 50, ranging from 40 to 80 hours for those who identified themselves as clinical researchers. Research accounted for the largest amount of time spent when compared to all work-related activities at 45\% (range: 5\%-75\%). Clinical duties were approximately $40 \%$ (range: $4 \%-80 \%$ ) with academic activities accounting for another 10\% (range: $2 \%-64 \%)$. This contrasted sharply with income source where $70 \%$ (range: $5 \%-99 \%$ ) of their income coming from clinical duties with just 28\% (range: $2 \%-75 \%$ ) for research (Table 3). Respondents indicated that they received support in the form of office space, administrative support, and methodology support. Eighty-six percent of respondents receive some salary support for research. Most researchers (81\%) belonged to an affiliated research institute.

We assessed career satisfaction for clinical researchers (Table 4). We found that $83 \%$ were either satisfied or very satisfied with the research aspect of their career. 

number of trained clinician scientists in emergency medicine?"

\begin{tabular}{|c|c|c|c|}
\hline Lead Author & Title of Article & Article type & Relevant Objective \\
\hline \multicolumn{4}{|c|}{ General Emergency Medicine Research } \\
\hline Kaji, AH & $\begin{array}{l}\text { Summary of NIH Medical-Surgical } \\
\text { Emergency Research Roundtable } \\
\text { Held on April } 30 \text { to May 1, } 2009\end{array}$ & $\begin{array}{l}\text { Conference } \\
\text { Proceeding }\end{array}$ & $\begin{array}{l}\text { To identify the challenges and } \\
\text { gaps in emergency care } \\
\text { research }\end{array}$ \\
\hline
\end{tabular}

Main Results

Koroshetz, WJ

$\mathrm{NIH}$ and Research in the Emergency Setting: Progress, Promise, and Process

Landman, A

The Robert Wood Johnson Foundation Clinical Scholars Program for Emergency Medicine
Comment

To identify current roadblocks, note solutions, and set priorities for research

To describe the Robert Wood Johnson Foundation Clinical Scholars Program for Emergency Medicine Researchers and highlight its successes

To describe the steps necessary to undertake successful research acknowledging the barriers of inadequate training, insufficient time and inadequate funding

Summary

Lack of Research Training: It was identified that there is a shortage of adequately trained investigators - few emergency physicians have completed rigorous research training and this was felt to be due to lack of role models and training opportunities. Poor infrastructure: It was identified that there is inadequate protected time for research, poorly defined research-based career tracks and professional incentives distract investigators from research-based careers. Poor linkages: It was identified that there is an inadequate number of interdisciplinary research collaborations and multi-institutional networks. There are also significant gaps in data linkages and standardization of clinical care and information system. Insufficient funding: It was identified that there was insufficient amount of funding. Additionally, it was noted that funding is often aligned along diseases - which is difficult as in emergency care, patients are often undifferentiated.

Diversity of Emergency Medicine Research: The NIH funds high quality emergency care investigators who study diverse areas. Clinical Translational Science Awards Program: Is noted to be a potential source of funding for supporting infrastructure and the development of new investigators in emergency care research.

Program: Graduating residents interested in health policy and health services research can apply to this 2-year program at a participating site. All sites provide core research training and acquire the skills to engage stakeholders and apply their research using community-based participatory research methods. Scholars receive mentoring and may earn a master's degree during the program. Success of Program: At the time of publication, $41 \mathrm{EM}$ scholars had completed the program. Many had become academic leaders and are highly productive researchers.

Inadequate Training: Describes the importance of acquiring research training and mentorship. Insufficient Time: "The only way to obtain sufficient time to be a highly productive investigator is to resolve the third problem of inadequate funding". Inadequate funding. Demonstrates the importance of funding to protect time.

Training: Support individuals with great promise and commitment to consequential research - encourage rigorous training through

fellowships and degree programs. Academic Departments: Develop a strategic plan to develop or improve research strategies and capabilities. Extramural funding: Advocate for research support from philanthropic foundations and government agencies to advance the state of emergency medicine research. National emergency

medicine organizational efforts: 1 . Establish a multi-organization research council that can address common priorities. 2.Establish longterm relationships with policymakers and the public to provide information and discuss the benefits and contributions of emergency 
Table 1. (Continued)

\begin{tabular}{|c|c|c|c|c|}
\hline Lead Author & Title of Article & Article type & Relevant Objective & Main Results \\
\hline & & & & $\begin{array}{l}\text { medicine research. Multicenter research: Focus on supporting } \\
\text { interdepartmental, long-term multicenter relationships. New } \\
\text { methods and outcome measurement: Become proficient in the } \\
\text { methodology of measuring and reporting outcomes of emergency } \\
\text { medicine care, direct research, and education to reduce variability in } \\
\text { emergency care and develop quantifiable outcome measures for } \\
\text { safety net care. }\end{array}$ \\
\hline \multicolumn{5}{|r|}{ 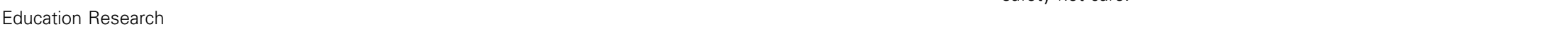 } \\
\hline LaMantia, J & $\begin{array}{l}\text { Faculty Development in Medical } \\
\text { Education Research }\end{array}$ & $\begin{array}{l}\text { Conference } \\
\text { Proceeding }\end{array}$ & $\begin{array}{l}\text { To identify the most successful } \\
\text { method of promoting faculty } \\
\text { development in education } \\
\text { research in EM }\end{array}$ & $\begin{array}{l}\text { Medical Education Fellowship: Important in developing strong } \\
\text { foundation medical education research skills - often involves a } \\
\text { masters-level degree. Medical Education Research Groups: Offer } \\
\text { support and a network of collaboration. Increased Mentoring: } \\
\text { Increase the availability of mentors to help guide junior faculty } \\
\text { interested in educational scholarships. }\end{array}$ \\
\hline LaMantia, J & $\begin{array}{l}\text { Executive Summary: Education } \\
\text { Research in Emergency Medicine- } \\
\text { Opportunities, Challenges and } \\
\text { Strategies for Success }\end{array}$ & $\begin{array}{l}\text { Conference } \\
\text { Proceeding }\end{array}$ & $\begin{array}{l}\text { Defining a core curriculum for } \\
\text { education research } \\
\text { fellowships and promoting } \\
\text { faculty development in } \\
\text { education research }\end{array}$ & $\begin{array}{l}\text { Defining a core curriculum for education research fellowships } 1 \text {. } \\
\text { Review existing postgraduate fellowship structures. 2. Match unique } \\
\text { needs of an education research fellowship to a conducive structure. } 3 \text {. } \\
\text { Identify core content for a postgraduate education research } \\
\text { fellowship. } 4 \text {. Propose an ideal structure for the fellowship, including } \\
\text { duration, formal training opportunities, fellowship role, integration into } \\
\text { department, and funding logistics. Promoting faculty development } \\
\text { in education research } 1 \text {. Outline best strategies to translate } \\
\text { education methods supported by research into teach-the-teacher } \\
\text { curricula. 2. Examine current available opportunities for postgraduate } \\
\text { education research training in EM and other fields (such as education } \\
\text { research fellowship, MERC, etc.); construct core content to guide } \\
\text { development of new training opportunities. 3. Commit to alliances } \\
\text { with education scientists across a broad range of clinical specialties } \\
\text { and outside of medicine, with the goal of creating a common research } \\
\text { agenda and shared resources. } 4 \text {. Develop strategies for recruiting and } \\
\text { mentoring future EM education researchers. }\end{array}$ \\
\hline Love, JN & $\begin{array}{l}\text { The MERC at CORD Scholars Program } \\
\text { in Medical Education Research: A } \\
\text { Novel Faculty Development } \\
\text { Opportunity for Emergency } \\
\text { Physicians }\end{array}$ & Comment & $\begin{array}{l}\text { To describe the Medical } \\
\text { Education Research } \\
\text { Certification (MERC) at the } \\
\text { Council of Emergency } \\
\text { Medicine Residency } \\
\text { Directors (CORD) Scholars } \\
\text { Program }\end{array}$ & $\begin{array}{l}\text { The MERC at CORD is a program that brings emergency medicine } \\
\text { education scholars from multiple institutions together to develop a } \\
\text { mentored, collaborative research project and apply the concepts } \\
\text { learned through MERC workshops. }\end{array}$ \\
\hline \multicolumn{5}{|l|}{ EMS Research } \\
\hline Sayre, MR & $\begin{array}{l}\text { National EMS Research Agenda: } \\
\text { Proceedings of the Implementation } \\
\text { Symposium }\end{array}$ & $\begin{array}{l}\text { Conference } \\
\text { Proceeding }\end{array}$ & $\begin{array}{l}\text { To disseminate the EMS } \\
\text { Research Agenda, to } \\
\text { encourage a collaborative } \\
\text { vision that provides direction } \\
\text { to EMS research, and to } \\
\text { initiate the process of } \\
\text { building a foundation and } \\
\text { infrastructure for future EMS } \\
\text { research }\end{array}$ & $\begin{array}{l}\text { Improve training: A large cadre of career EMS investigators should be } \\
\text { developed and supported in the initial stages of their careers. Highly } \\
\text { structured training programs with content directed toward EMS } \\
\text { research methodologies should be developed. Increased funding: } \\
\text { Describes opportunities at NIH that EMS researchers would be } \\
\text { eligible for. }\end{array}$ \\
\hline
\end{tabular}


This compared with $88 \%$ who were satisfied or very satisfied with the clinical aspect of their career and $63 \%$ who were satisfied or very satisfied with the education aspect (e.g., teaching medical students, residents, or fellows) of their career. In response to the question on

\begin{tabular}{|c|c|c|}
\hline Training/education & $N$ & $\%$ \\
\hline \multicolumn{3}{|l|}{ Training } \\
\hline FRCPC-EM & 25 & 60 \\
\hline CCFP-EM & 10 & 24 \\
\hline PEM Fellowship & 4 & 10 \\
\hline CCFP & 1 & 2 \\
\hline Informal & 1 & 2 \\
\hline FCEM & 1 & 2 \\
\hline \multicolumn{3}{|l|}{ Graduate education } \\
\hline MSc (Epidemiology) & 15 & 51 \\
\hline MSc & 6 & 21 \\
\hline $\mathrm{PhD}$ & 4 & 14 \\
\hline $\mathrm{MPH}$ & 3 & 11 \\
\hline MEd & 1 & 3 \\
\hline \multicolumn{3}{|c|}{$\begin{array}{l}\text { FRCPC-EM }=5 \text { year Royal College of Physicians and Surgeons of Canada Emergency } \\
\text { trained } \\
\text { CCFP-EM }=2 \text { year Family Medicine Residency plus } 1 \text { year Emergency Medicine } \\
\text { Training } \\
\text { PEM Fellowship }=4 \text { years Pediatrics Residency plus } 2 \text { years Emergency Medicine } \\
\text { Training } \\
\text { CCFP }=2 \text { years of Family Medicine Residency } \\
\text { FCEM = Fellow of the College of Emergency Medicine (United Kingdom) } \\
\text { MSC = Master's in science } \\
\text { PhD = Doctorate } \\
\text { MPH = Master's in public health } \\
\text { MEd = Master's in education }\end{array}$} \\
\hline
\end{tabular}

Table 3. The median percent time commitment and median income percent of clinical researchers stratified by professional roles $(n=42)$

\begin{tabular}{|c|c|c|c|c|c|c|}
\hline \multirow[b]{2}{*}{ Professional role } & \multicolumn{3}{|c|}{ Time } & \multicolumn{3}{|c|}{ Income source } \\
\hline & $\begin{array}{c}\text { Median } \\
(\%)\end{array}$ & $\begin{array}{l}\text { Min } \\
(\%)\end{array}$ & $\begin{array}{l}\text { Max } \\
(\%)\end{array}$ & $\begin{array}{c}\text { Median } \\
(\%)\end{array}$ & $\begin{array}{l}\text { Min } \\
(\%)\end{array}$ & $\begin{array}{l}\text { Max } \\
(\%)\end{array}$ \\
\hline Clinical duties & 40 & 4 & 80 & 70 & 5 & 99 \\
\hline Research commitment & 45 & 5 & 75 & 28 & 2 & 75 \\
\hline Academic duties & 10 & 2 & 64 & 10 & 1 & 60 \\
\hline Other responsibilities & 10 & 2 & 70 & 13 & 2 & 55 \\
\hline
\end{tabular}

work and life balance, over half (55\%) were either satisfied or very satisfied; however, one-quarter of respondents were either dissatisfied or very dissatisfied. We found that $76 \%$ reported that they would probably or definitely conduct research within 5 years, and only $5 \%$ indicated that they would probably not be involved in research in 5 years. The single largest constraint to conducting research was lack of funding (e.g., salary support to grant funding), followed by the time required for clinical commitments. Factors felt to be positive contributors to having a clinical research career were salary support, research training (including an advanced graduate degree), mentorship, and infrastructure.

\section{International emergency medicine research fellowship programs}

The only structured emergency medicine research training program we identified was that of SAEM. The panel discussed this program with one of the leaders, Dr.Judd Hollander, who was also invited to participate on our expert panel. SAEM provides a certificate of training to research fellows who complete a 2-year program at an accredited SAEM training site. An advanced research degree is required plus additional emergency medicine research training to train emergency care researchers to conduct research using a broad range of study designs and analytical techniques. They must meet specific objectives covering 15 broad categories. Fellows are required to take an idea from conception through ethics approval, submit a manuscript related to their main emergency care research project, and write and submit a large grant to a national granting agency. ${ }^{16,17}$

\section{Academic Symposium}

Several issues were brought forward and discussed at the symposium. Specifically, attendees stressed the importance of mentorship, project management, importance of a period of training after graduate training (i.e., a post-doctoral period) to consolidate knowledge and skills

Table 4. Career satisfaction among emergency medicine clinician researchers $(n=42)$

\begin{tabular}{lcccc}
\hline Career satisfaction & Very dissatisfied or dissatisfied (\%) & Neutral (\%) & Very satisfied or satisfied (\%) & Not applicable (\%) \\
\hline Research career & 7 & 10 & 83 & 0 \\
Clinical career & 7 & 5 & 88 & 0 \\
Education career & 3 & 23 & 63 & 12 \\
Work and life balance & 24 & 21 & 55 & 0
\end{tabular}


prior to obtaining a first academic appointment. This enables the young investigator the opportunity to develop an academic track record in publications, grants, awards, and abstracts, which ultimately will make them more competitive. Additional feedback from academic symposium attendees suggested that the CAEP Academic Section should be the body to endorse these training centres. It was felt that accreditation or more complex review of centres or individuals, similar to SAEM, would not be feasible. There was also considerable debate concerning the amount of grant funding we should suggest as a reasonable target to demonstrate success. It was recognized that some areas of research are considerably more difficult to obtain high dollar amounts of funding, and high levels of funding may not be required to complete impactful research (e.g., qualitative research and medical education research). As such, a specific funding target was removed from the panel recommendations. It was also recognized that smaller centres could formally link with other centres to ensure that their trainees obtained all elements for Phase I and Phase II training.

\section{DISCUSSION}

Although very little data were available in the literature to inform recommendations to create formal standards for postgraduate emergency medicine research training programs, the existing information had a common theme of strong mentorship, protected time, graduate training, and infrastructure as being very important for clinician scientists. The SAEM fellowship training program attempts to standardize the training of clinician researchers to a high level of functionality. ${ }^{13,14}$ Although the SAEM program is very rigorous, this program does not provide for a period of consolidation following graduate degree completion. Strong mentorship has been encouraged in the literature during this transitional time period. ${ }^{2}$

Results from our survey suggested that emergency medicine clinician scientists strongly believe that research training with a graduate degree, salary support, and mentorship are all strong factors providing a positive impact on a clinical research career. Conversely, obtaining grants was the single biggest constraint to conducting research, with clinical commitments a distant second. Without strong research training, including an advanced degree and ongoing mentorship, it is extremely difficult to obtain large grants to support research studies and build a research program. It is even more difficult to obtain one of the few available salary support awards.

Our recommendations consolidate the information from our systematic review, the survey, the SAEM research fellowship program, and feedback from the Academic Symposium at CAEP 2014. We believe that the SAEM research fellowship is comprehensive, and, as such, most of the learning topics within their list of mandatory learning requirements are applicable in Canada. Some aspects of the SAEM program need to be adapted for Canada. We believe that different training centres could formalize links in order to adequately cover all core learning topics, without requiring research trainees to relocate. We also believe that submission of at least one grant to any peer-reviewed provincial or national organization would be adequate, and we did not set a specific dollar amount to this application. Further, additional postgraduate training, at either the same or a different institution, is valuable and will help consolidate the theory learned in the first 2 years of research training. Salary support, protected time (i.e., reduced number of shifts, administrative, and teaching), and infrastructure are critical to the success of research trainees.

\section{RECOMMENDATIONS}

\section{a. Two phases of research training}

Our panel endorses the importance of a structured research training program. It was agreed that this optimally would consist of two phases: Phase I: Fellowship/graduate training in research (2 years) and Phase II: Research consolidation (1-3 years).

Phase I: Fellowship/graduate training will consist of formal research training, including an advanced research degree (e.g., master's in epidemiology). In addition to the classroom education, practical knowledge needs to be acquired through mentorship and experience. A list of 15 learning topics for Phase I: Fellowship/graduate training in research is outlined in Figure 2. Protected time by ensuring limited clinical shifts, limited teaching and administrative responsibilities, and providing a research salary were felt to be essential for success. Workspace with appropriate infrastructure (e.g., computer, Internet access, software, information technology, reference software, statistical software, and access to information specialists) was also deemed to be very important. During this time, trainees would learn how to bring a clinical question from 
Figure 2. Objectives for Phase I: research fellowship/ graduate training.

1. Identification of research focus within emergency medicine

2. Hypothesis generation

3. Research design

4. Data collection methods

5. Data monitoring and interim data analysis

6. Data analysis

7. Presentation of research

8. Manuscript preparation, submission, and revision

9. Knowledge translation

10. Project management

11. Ethical aspects of medical research

12. Regulatory requirements

13. Informatics

14. Teaching skills

15. Career development

Figure 3. Objectives for Phase II: research consolidation training.

1. Submit and present two or more scientific abstracts per year.

2. Submit at least two full manuscripts as first author per year.

3. Obtain at least one grant from a provincial or national peer-review organization, including preparation, submission, and revision.

4. Consolidation of learning points from Phase I (from 1-15)

hypothesis generation, protocol development, through ethics review, implementation, analysis, presentation, and manuscript production.

Phase II: Research consolidation training will consist of intense mentoring to transition to independent research. This period will be for $1-3$ years at the discretion of the individual and their mentor. It is important that the new clinician scientists be registered with their academic institutions as postdoctoral trainees during this period, such that their "academic clock" (i.e., the date used for determining eligibility for salary awards and academic promotion) is not activated until they are ready to be fully independent clinician researchers. Figure 3 lists the requirements for Phase II training, which focuses on grant writing, abstract presentations, manuscript production, building a network, national and international exposure, and consolidation of the 15 learning topics in Phase I training.

\section{b. Create a Canadian Association of Emergency Physicians endorsement process}

We recommend that CAEP initiate an endorsement process for institutions wishing to offer advanced research training. This would include a specific plan on how to ensure that clinical research trainees meet the objectives for Phase I and Phase II. This will allow for standardization of training, production of high quality researchers, and increase our academic productivity and our capacity in research.

\section{LIMITATIONS}

Although the literature search strategy we used was comprehensive, it is possible we could have missed relevant articles or articles from the grey literature. The survey was completed by Canadian emergency medicine clinician scientists who were identified by others as part of another survey. The strategy of having physicians self-identify as being a clinical researcher may introduce some bias. This could have resulted in some prolific researchers not identifying themselves as a clinician scientist. This could skew the results toward fewer hours spent on research and less financial support. However, this was mitigated by the experienced researchers on the panel assessing the list. We assessed the results of respondents not self-identifying as clinical researchers for time spent conducting research, which found a median of $10 \%$ of their time spent conducting research. Hence, it is very unlikely that we misclassified clinician researchers. It is also possible that some researchers were not identified by the environmental scan. This could result in some coverage error, where some of our target population did not have a chance to respond. We believe that the emergency medicine research community in Canada is sufficiently small that the members of our panel would have been able to identify most, if not all, prolific researchers not identified by the scan. Finally, our recommendations were developed based on the literature, survey data, and input from stakeholders; however, it is possible that key components not brought forward by those attending the academic symposium or by those from whom we sought feedback were missed.

\section{CONCLUSIONS}

Very sparse data are available regarding optimal training to become a clinician scientist in emergency medicine. Common themes to facilitate research training included 1) creating training opportunities; 2) ensuring adequate protected time; 3) salary support; 4) infrastructure; and 5) mentorship. Our survey identified obtaining a graduate research degree, salary support, and mentorship as strong 
factors that positively impact a clinical research career. We recommend that the CAEP Academic Section create a process to endorse research training programs. These programs should include two phases: 1) Fellowship/ graduate training, including an advanced research university degree and 15 core learning areas; and 2) Research consolidation, including a further 1-3 years with an emphasis on mentorship and scholarship production. It is anticipated that clinician scientists completing Phase I and Phase II training at a CAEP Academic Sectionendorsed site(s) will be independent researchers with a higher likelihood of securing external peer-reviewed funding and be able to have a meaningful external impact in emergency medicine research.

Acknowledgements: All of the recommendations from the CAEP 2015 Academic Symposium are published in the Executive Summary and articles from each panel. ${ }^{3,4,5} \mathrm{We}$ are thankful to all of the physicians who took the time to complete our survey. We gratefully acknowledge the invaluable assistance of the following individuals: Dr. Stephen Freedman (Department of Epidemiology, University of Calgary, Calgary, Alberta); Dr. Robert Green (Department of Emergency Medicine, Dalhousie University, Halifax, Nova Scotia); Angela Marcantonio (Ottawa Hospital Research Institute, Ottawa, Ontario); and Catherine Clement (Ottawa Hospital Research Institute, Ottawa, Ontario).

Competing interests: None declared.

\section{SUPPLEMENTARY MATERIAL}

To view supplementary material for this article, please visit http://dx.doi. org/10.1017/cem.2015.63

\section{REFERENCES}

1. Phillipson EA. Is it the clinician-scientist or clinical research that is the endangered species? Clin Invest Med 2002;25(1-2):23-5.

2. Phillipson EA. Clinical/research residency programs for the clinician scientist. Clin Invest Med 1997;20(4):259-60.

3. Stiell et al. Executive Summary of the CAEP 2014 Academic Symposium: How to make research succeed in your emergency department. CFEM 2015;17(3):328-33.

4. Vaillancourt et al. CAEP 2014 Academic Symposium: "How to make research succeed in your emergency department:
How to fund your research program." CFEM 2015; forthcoming.

5. Calder et al. CAEP 2014 Academic Symposium: "How to make research succeed in your emergency department: Promoting excellence in Canadian emergency medicine resident research." CFEM 2015; forthcoming.

6. Kaji AH, Lewis RJ, Beavers-May T, et al. Summary of NIH Medical-Surgical Emergency Research Roundtable held on April 30 to May 1, 2009. Ann Emerg Med 2010;56(5):522-37.

7. Sayre MR, White LJ, Brown LH, McHenry SD. National EMS research agenda: proceedings of the implementation symposium. Acad Emerg Med 2003;10(10):1100-8.

8. Yarris LM, Coates WC, Lin M, et al. A suggested core content for education scholarship fellowships in emergency medicine. Acad Emerg Med 2012;19(12):1425-33.

9. Koroshetz WJ. NIH and research in the emergency setting: progress, promise, and process. Ann Emerg Med 2010; 56(5):565-7.

10. LaMantia J, Hamstra SJ, Martin DR, et al. Faculty development in medical education research. Acad Emerg Med 2012;19(12):1462-7.

11. LaMantia J, Deiorio NM, Yarris LM. Executive summary: education research in emergency medicine-opportunities, challenges, and strategies for success. Acad Emerg Med 2012;19(12):1319-22.

12. Landman A, Meisel ZF. The Robert Wood Johnson Foundation Clinical Scholars Program and emergency medicine. Acad Emerg Med 2010;17(4):e17-22.

13. Ling LJ. Proceedings of the Future of Emergency Medicine Research Conference, part I: executive summary. Acad Emerg Med 1998;5(2):147-51.

14. Love JN, Coates WC, Santen SA, et al. The MERC at CORD Scholars Program in medical education research: a novel faculty development opportunity for emergency physicians. Acad Emerg Med 2009;16(Suppl 2):S37-41.

15. Lubavin BV, Langdorf MI, Blasko BJ. The effect of emergency medicine residency format on pursuit of fellowship training and an academic career. Acad Emerg Med 2004;11 (9):938-43.

16. Society for Academic Emergency Medicine (SAEM). Fellowship Approval Program. Society for Academic Emergency Medicine, 2014. Available at: http://www.saem.org/ education/fellowship-approval-program/research-fellowship (accessed May 2014).

17. Society for Academic Emergency Medicine (SAEM). Application for Emergency Medicine Institutional Research Fellowship Program. Society for Academic Emergency Medicine, 2014. Available at: http://www.saem.org/docs/fellowship-approval/research_fellowship_program_rfa_2014.pdf? sfvrsn $=0$ (accessed May 2014). 